\title{
Lessons Learned From Using An Ill-Conceived Nonmonetary, Prepaid Incentive In A Self-Administered Survey Of College Students
}

\author{
Curt J. Dommeyer, Ph.D., California State University, Northridge, USA
}

Melissa Romero, Marketing Undergraduate, California State University, Northridge, USA

Kevin M. Tafazzoli, Marketing Undergraduate, California State University, Northridge, USA

\begin{abstract}
An experiment was conducted to determine how effective a prepaid, nonmonetary incentive would be at inducing college students to participate in a self-administered survey. The experiment was conducted on two college campuses in Los Angeles County. As students exited their campus library, an interviewer approached them for an interview. Half of those approached were offered a prepaid, nonmonetary incentive; the other half were not. Contrary to expectations, the prepaid, nonmonetary incentive dampened the response rate to the survey. Explanations are offered as to why the incentive was counterproductive.
\end{abstract}

Keywords: incentive, self-administered survey, response rate

\section{INTRODUCTION}

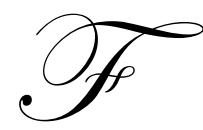

or decades, researchers have conducted numerous experiments to determine how incentives affect response to mail surveys. It has been concluded, in most cases, that prepaid incentives produce higher response rates than promised ones (Berk et al. 1987; Church 1993; Gajraj et al. 1990; Gelb 1975; Goodstadt et al. 1977; Goyder 1994; Singer 2002; Wotruba 1966), that monetary incentives yield higher response rates than nonmonetary gifts (Church 1993; Hansen 1980; Ryu et al. 2005; Singer et al. 1999), that larger incentives are associated with larger response rates (Church 1993; Yu and Cooper 1983), and that diminishing marginal returns occur as incentive value increases (Armstrong 1975; Fox et al. 1988).

Response rate is only one measure of survey response. Response quality (often measured by the number of questionnaire items answered and by the number of words used to answer open-ended questions) is another key survey response variable. Social exchange theory has been used to explain how incentives, especially prepaid ones, should have a positive impact on response quality (Dillman 2007). The prepayment of an incentive not only offers a reward to the potential survey respondent but also makes it more likely that the potential respondent will trust the survey administrator. These factors should motivate respondents to respond completely to a survey. Hansen (1980), on the other hand, uses self-perception theory to explain how an incentive serves as an external motivator of response. Since an incentive is likely to attract survey respondents who are not intrinsically interested in the questionnaire topic, responses to the questionnaire items are likely to be cursory and incomplete. Although most studies have found that incentives do not adversely affect response quality (Davern et al. 2003; Shettle and Mooney 1999; Singer et al. 1999), a few have found that they marginally increase response quality (Singer et al. 2000; Willimack et al. 1995).

Sample bias, the tendency for an incentive to attract responses from specific segments of the population, is another variable of interest. It is often measured by comparing treatment and control groups on demographic variables measured in the survey or by comparing those who do and do not respond to a survey incentive on 
demographic data found in public records. Most of the studies that have examined the effect that survey incentives have had on sample bias have not found that the incentives have created any serious sampling distortions (Goyder 1994; Singer et al. 1999; Willimack et al. 1995). Some have argued that incentives can be used to attract those who otherwise might be underrepresented in a survey, e.g., people of low income or minorities (Singer et al. 1999; Martin et al. 2001). Mack et al. (1998), for example, found that a $\$ 20$ incentive was effective at recruiting panel members from black and low income households, while Abreu et al. (1999) found that a \$20 incentive was successful at recruiting people of low income to a panel.

Previous researchers have emphasized that the impact an incentive will have on survey response will be related to the mode of interviewing (Lynn 2001; Singer et al. 1999). Other than having an attractive survey sponsor or an interesting survey topic, mail surveys are limited in their ability to motivate a survey response. In a mail survey, an incentive should stand out to serve as a prime motivator of response. However, the use of an incentive with a personally distributed survey would seem to be less effective, for the persuasive properties of the survey distributor (e.g., his or her physical attractiveness, personality, and charm) could swamp the effect of any incentive. Although little research has been published that directly investigates how survey mode and survey incentives interact with each other (for an exception, see Ryu et al. 2005), a couple of reviews of the literature suggest that incentives are more effective in mail surveys. In his meta-analysis of the mail survey literature, Church (1993) found that incentives cause, on average, an increase of the response rate by 13 percentage points. Singer (1999), in contrast, found that incentives increase the response rate to interviewer-mediated surveys by about three percentage points (Lynn 2001).

Although incentives have been well researched in mail surveys, relatively little is known how incentives affect the response to interviewer-mediated surveys. The purpose of the present study is to determine how a nonmonetary, prepaid incentive affects response to a personally distributed, self-administered survey among college students.

\section{METHODOLOGY}

A self-administered, four-page survey was created to measure college students' attitudes towards websites that rate professors, e.g., ratemyprofessor.com. The survey consisted of 31 questions, some of which required multiple responses.

The surveys were distributed to college students at two colleges in Los Angeles

County - one campus is a two-year community college while the other is a large, four-year public university. At each campus, 100 survey attempts were made outside of each campus' main library. During the period of the survey, students exiting their library were approached by either a male or female student-aged interviewer for an interview.

In half of the survey attempts at each campus' library, students exiting the library were greeted and asked to complete the self-administered survey. These students constituted the "control" group.

In the other half of the survey attempts, students exiting their library were first offered a free Scantron form. Both colleges in this study require students to furnish their own Scantron forms when taking an exam. Since a Scantron form costs 28 cents (when purchased individually) and since it can be inconvenient for a student to travel to the bookstore to purchase a form, we felt that the form would be an attractive incentive for most students. Any student who accepted the free Scantron form was then asked to participate in the survey. Any student who refused the Scantron form was not asked to participate in the survey. All students who were offered the Scantron form constituted the "treatment" group.

To minimize any order effects, the treatment and control conditions were systematically altered throughout the interviewing process at each campus. After every ten survey attempts, each interviewer altered whether he or she did or did not offer the Scantron form to the person who was approached for an interview. This process was continued until 50 survey attempts were made with the incentive and 50 were made without the incentive at each of the two campuses. A total of 200 survey attempts were made - 100 with the prepaid incentive and 100 without. 
The treatment and control groups were compared on the following three dependent variables: response rate, item omission rate, and sample bias. The response rate is defined as the number of usable questionnaires received divided by the number of attempted interviews. A questionnaire was considered usable only if at least $50 \%$ of the questions were answered. The item omission rate is defined as the average number of questions left unanswered among those questions that everyone should have answered. In this survey, only eight of the 31 items on the survey are ones that should have been answered by all respondents. Skipping instructions could have allowed some respondents to legitimately skip up to 23 items. Therefore, the item omission rate is based only on those eight questions that all respondents should have answered. Finally, sample bias was measured by comparing the treatment and control groups on their answers to five demographic questions, namely sex, age, class standing, major, and GPA.

\section{RESULTS}

Results were initially examined for each campus separately. Each campus produced similar results. Therefore, the results from both campuses were analyzed together.

We had expected that our incentive would draw students into the survey. Contrary to our expectations, we discovered those in the treatment group were less likely to respond to the survey than those in the control group $\left(16 \%\right.$ vs. $\left.31 \%, \mathrm{X}^{2}(1)=5.45, \mathrm{p}<.025\right)$.

Both the treatment and control groups had similar item omission rates (treatment group $=.06$ vs. control group $=.31, \mathrm{t}(45)=1.07, \mathrm{p}>.10$ ). Moreover, there was no evidence of any sample bias when comparing the two groups on the five demographic variables.

\section{DISCUSSION AND CONCLUSIONS}

Our finding that the incentive dampened the survey response rate is rare and unexpected, but it is not unique. Church (1993) found that 10\% of the 74 survey incentive conditions that were included in his meta-analysis of mail survey experiments yielded negative results for the incentives.

Several theories suggest that incentives should be effective. The norm of reciprocity suggests that people should respond positively to people who have helped them (Goulder 1960). Cognitive dissonance theory indicates that a person who receives a gift may experience dissonance if they are unable to return the favor (Hackler and Bourgette 1973). Both of these theories, however, imply that a gift has been received by the subject. If the gift offer is refused or not received, there is very little opportunity for the incentive to engender reciprocal behavior or create dissonance. Unlike a mail survey, a self-administered survey can not ensure that a prepaid incentive will be received by the intended respondent. That was the case in our experiment. Many of those who were offered the free Scantron form simply refused it. Once they refused the incentive, they were under no obligation to the interviewer. Moreover, it appeared that offering of the Scantron form, in many cases, triggered a flight response. People were no doubt skeptical of the strings that may be attached to a "free offer." They, therefore, refused it and escaped the situation quickly. This kind of reaction prevented the interviewers from even asking the potential respondents to participate in the survey. Consequently, the incentive, in many of our cases, killed the interview attempt. Most of those who accepted the free Scantron form did consent to the interview. But there were far too few people who accepted the free gift to make the prepaid incentive effective.

Another factor that hurt our incentive's chances of being successful was its lack of perceived value. We thought that most students would appreciate receiving a free Scantron form. We discovered, however, that many of the students we encountered were not taking a summer school class. And some of the others we encountered, though in class, had no immediate need for a Scantron form. Another problem we encountered was offering the Scantron form to students who had no safe place to store it. Thus, giving them a Scantron form placed them in an awkward situation. In summary, the perceived value of our incentive was insufficient to motivate most of those in the treatment group to respond to our survey.

It is clear from this study that an incentive for a self-administered survey - whether it be prepaid or postpaid 
- must be of sufficient value to attract the majority of potential respondents. Researchers considering various incentives should pretest them to determine which one would have the greatest chances of being successful. Future researchers might also consider offering a selection of incentives to the potential respondent. Allowing the potential respondent to select one incentive from a batch of incentives should increase the odds that all the potential respondents would be receptive to a survey invitation.

\section{AUTHOR INFORMATION}

Curt J. Dommeyer received his Ph.D. in business administration from the University of Cincinnati. He is currently a Professor of Marketing at California State University, Northridge. His primary research interests include survey methodology, marketing pedagogy, business etiquette, and identity theft. Professor Dommeyer has over 20 journal publications. Among the journals in which he has publications are Psychology \& Marketing, Industrial Marketing Management, Journal of Interactive Marketing, International Journal of Market Research, Journal of Marketing Education, Marketing Education Review, Assessment and Evaluation in Higher Education, and the Journal of Education for Business.

Melissa Romero is currently a senior at California State University, Northridge (CSUN). She is scheduled to graduate in May of 2009 with a bachelor's degree in business marketing. Ms. Romero is currently the Homecoming/Spirit director for the Associated Students at CSUN. She is scheduled to teach a class on planning high profile events on college campuses at the National Association for Campus Activities (NACA) West Regional and National Conferences.

Kevin M. Tafazzoli is a senior undergraduate at California State University, Northridge. Mr. Tafazzoli is a marketing major expecting to graduate with his bachelor's degree in the spring of 2009. He is currently interning at J.D. Power and Associates at the firm's offices in Westlake Village, California. Mr. Tafazzoli works directly with the company's vice president contributing to research for televisions, tires, and dealerships. His current research interest focuses on how evolving technologies, such as telecommunications, affect consumer behavior. He eventually wants to determine how promotions can be more effectively used to capture market share and sales.

\section{REFERENCES}

1. Abreu, D. A., Martin, E., \& Winters, F. (1999). Money and motive: Results of an incentive experiment in the survey of income and program participation. Presented at the International Conference on Survey Nonresponse, Portland, Oregon.

2. Armstrong, J. S. (1975). Monetary incentives in mail surveys. Public Opinion Quarterly, 39, 111-116.

3. Berk, M. L., Mathiowetz, N. A., Ward, E. P., \& White, A. A. (1987). The effect of prepaid and promised incentives: Results of a controlled experiment. Journal of Official Statistics, 3(4), 449-457.

4. Church, A. H. (1993). Estimating the effect of incentives on mail survey resonse rates: A meta-analysis. Public Opinion Quarterly, 57, 62-79.

5. Davern, M., Rockwood, T. H., Sherrod, R., \& Campbell, S. (2003). Prepaid monetary incentives and data quality in face-to-face interviews: Data from the 1996 survey of income and program paricipation incentive experiment. Public Opinion Quarterly, 67(1), 139-147.

6. Dillman, D. A. (2007). Mail and Internet Surveys: The Tailored Design Method. Hoboken, New Jersey: John Wiley \& Sons, Inc.

7. Fox, R. J., Crask, M. R., \& Kim, J. (1988). Mail survey response rate: A meta-analysis of selected techniques for inducing response. Public Opinion Quarterly, 52, 467-491.

8. Gajraj, A. M., Faria. A. F., \& Dickinson, J. R. (1990). A comparison of the effects of promised and provided lotteries, monetary and gift incentives on mail survey response rate, speed and cost. Journal of the Market Research Society, 32(1), 141-162.

9. Gelb, B. D. (1975). Incentives to increase survey returns: Social class considerations. Journal of Marketing Research, 12, 107-109.

10. Goodstadt, M. S., Chung, L., Kronitz, R., \& Cook, G. (1977). Mail survey response rates: Their manipulation and impact. Journal of Marketing Research, 14, 391-395. 
11. Gouldner, A. W. (1960). The norm of reciprocity: A preliminary statement. American Sociological Review, 25, 161-178.

12. Goyder, J. (1994). An experiment with cash incentives on a personal interview survey. Journal of the Market Research Society, 36(4), 360-366.

13. Hackler, J. C., \& Bourgette, P. (1973). Dollars, dissonance and survey returns. Public Opinion Quarterly, 37, 276-281.

14. Hansen, R. A. (1980). A self-perception interpretation of the effect of monetary and nonmonetary incentives on mail survey response behavior. Journal of Marketing Research, 17, 77-83.

15. Kalafatis, S. P., \& Madden, F. J. (1995, April). The effect of discount coupons and gifts on mail survey response rates among high involvment respondents. Journal of the Market Research Society, 37(2), 171184.

16. Lynn, P. (2001). The impact of incentives on response rates to personal interview surveys: Role and perceptions of interviewers. International Journal of Public Opinion Research, 13(3), 326-336.

17. Mack, S., Huggins, V., Keathley, D., \& Sundukchi, M. (1998). Do monetary incentives improve response rates in the survey of income and program participation? Proceedings of the Section on Survey Methodology, American Statistical Associaton, 529-534.

18. Martin, E., Abreu, D., \& Winters, F. (2001). Money and motive: Effects of incentives on panel attrition in the survey of income and program participation. Journal of Official Statistics, 17, 267-284.

19. Ryu, E., Couper, M. P., \& Marans, R. W. (2005, July). Survey incentives: Cash vs. in-kind; face-to-face vs. mail; response rate vs. nonresponse error. International Journal of Public Opinion Research, 18(1), 89-106.

20. Shettle, C., \& Mooney, G. (1999). Monetary incentives in U.S. government surveys. Journal of Official Statistics, 15(2), 231-250.

21. Singer, E. (2002). The use of incentives to reduce nonresponse in household surveys. In R. M. Groves, D. A. Dillman, J. L. Eltinge \& J. A. Little (Eds.), Survey Nonresponse (pp. 163-177). Chichester: Wiley.

22. Singer, E., Van Hoewyk, J. V., Gebler, N., Taghunathan, T., \& McGonagle, K. (1999). The effect of incentives on response rates in interviewer-mediated surveys. Journal of Official Statistics, 15(2), 217-230.

23. Singer, E., Van Hoewyk, J., \& Maher, M. P. (2000). Experiments with incentives in telephone surveys. Public Opinion Quarterly, 64(2), 171-188.

24. Willimack, D. K., Schuman, H., Pennell, B. E., \& Lepowski, J. M. (1995). Effects of a prepaid nonmonetary incentive on response rates and response quality in a face-to-face survey. Public Opinion Quarterly, 59, 78-92.

25. Wotruba, T. R. (1966). Monetary inducements and mail questionnaire response. Journal of Marketing Research, 3, 393-400.

26. Yu, J., \& Cooper, H. (1983). A quantitative review of research design effects on response rates to questionnaires. Journal of Marketing Research, 20, 36-44. 
Journal of Business \& Economics Research-September, 2009 Volume 7, Number 9 NOTES 